GRASAS Y ACEITES 68 (1)

January-March 2017, e179

ISSN-L: 0017-3495

doi: http://dx.doi.org/10.3989/gya.0797161

\title{
Regarding the rejection performance of a polymeric reverse osmosis membrane for the final purification of two-phase olive mill effluents previously treated by an advanced oxidation process
}

\author{
J.M. Ochando-Pulido ${ }^{\bowtie}$ and A. Martínez-Férez \\ Chemical Engineering Department, University of Granada, 18071 Granada, Spain \\ ${ }^{凶}$ Corresponding author: jmochandop@ugr.es
}

Submitted: 18 July 2016; Accepted: 13 December 2016

\begin{abstract}
SUMMARY: In previous works on olive mill wastewater (OMW), secondary advanced oxidation treatment solved the problem related to the presence of phenolic compounds and considerable chemical oxygen demand. However, the effluent presented a significant salinity after this treatment. In this work, an adequate operation of a reverse osmosis (RO) membrane is addressed to ensure constant performance over a long period of time. In this paper, the effect of the operating parameters on the dynamic membrane rejection performance towards the target species was examined and discussed. Rejection efficiencies of all species were observed to follow a similar pattern, which consisted of slight initial improvement that further decreased over time. Rejection of both divalent ions remained constant at over $99 \%$ regardless of the operating conditions. Rejections were noticed to follow the order $\mathrm{SO}_{4}{ }^{2-}>\mathrm{Cl}^{-}>\mathrm{NO}_{3}{ }^{-}$and $\mathrm{Ca}^{2+}>\mathrm{Mg}^{2+}>\mathrm{K}^{+}>\mathrm{Na}^{+}$, as a rule. Divalent species were moderately more highly rejected than monovalent ones, in accordance with their higher charge and molecular size, and sulfate anions were consistently rejected by over $99 \%$. Finally, the RO membrane exiting treated effluent was depleted of the high electro conductivity initially present (above 97\% rejection), permitting its re-use as good quality irrigation water (below $1 \mathrm{mS} / \mathrm{cm}$ ).
\end{abstract}

KEYWORDS: Effluents reclamation; Olive mill wastewater; Rejection; Reverse osmosis; Wastewater purification

RESUMEN: Sobre la eficiencia del rechazo de una membrana polimérica de ósmosis inversa para la purificación del agua residual de almazara de dos fases, previamente tratada mediante un proceso avanzado de oxidación. En trabajos previos con agua residual de almazara, se solucionó el problema en relación a la presencia de compuestos fenólicos y la considerable concentración de material orgánico. Sin embargo, el efluente presentaba una salinidad significativa tras éste. Este trabajo tiene por objetivo estudiar la adecuada operación de una membrana de ósmosis inversa (OI) para asegurar rendimientos constantes por largos períodos de tiempo de operación. Se examina y discute el efecto de los parámetros de operación en el rendimiento dinámico del rechazo de especies diana. Se observó que la eficiencia de rechazo de todas las especies siguió un patrón similar, consistente en una mejora inicial que posteriormente minoró con el tiempo de operación. El rechazo de iones divalentes se mantuvo constante sobre $99 \%$ independientemente de las condiciones de operación. La selectividad del rechazo siguió el orden $\mathrm{SO}_{4}{ }^{2-}>\mathrm{Cl}^{-}>\mathrm{NO}_{3}{ }^{-} \mathrm{yCa}^{2+}>\mathrm{Mg}^{2+}>\mathrm{K}^{+}>\mathrm{Na}^{+}$, en general. Las especies divalentes fueron moderadamente más rechazadas que las monovalentes, en concordancia con su mayor carga y tamaño molecular, y los iones sulfato fueron consistentemente rechazados al 99\%. Finalmente, el efluente a la salida de la membrana de OI se encontraba exento de los altos valores de conductividad inicialmente presentes (rechazo superior al 97\%), permitiendo su reutilización como agua de regadío de buena calidad (inferior a $1 \mathrm{mS} / \mathrm{cm}$ ).

PALABRAS-CLAVE: Agua residual de la industria oleícola; Ósmosis inversa; Purificación de aguas residuales; Recuperación de efluentes

ORCID ID: Ochando-Pulido JM http://orcid.org/0000-0001-5564-7619, Martínez-Férez A http://orcid.org/0000-0001-5750-7900

Citation/Cómo citar este artículo: Ochando-Pulido JM, Martínez-Férez A. 2017. Regarding the rejection performance of a polymeric reverse osmosis membrane for the final purification of two-phase olive mill effluents previously treated by an advanced oxidation process. Grasas Aceites 68, e179. http://dx.doi.org/10.3989/gya.0797161

Copyright: (C) 2017 CSIC. This is an open-access article distributed under the terms of the Creative Commons Attribution (CC-by) Spain 3.0 License. 


\section{INTRODUCTION}

The olive oil industry, which is widely known to be one of the main agro-industrial sectors of the countries in the Mediterranean Basin, produces two problematic wastewater streams: the first one comes from the washing of the olives, and is therefore called olives washing wastewater (OWW), and the second one is generated in the centrifugation process, and is referred to as olive mill wastewater, OMW, a mixture of the olive-fruit moisture along with the process-added water.

In traditional olive oil mills working with the ancient batch press method, increasingly less used, between $0.4-0.6 \mathrm{~m}^{3}$ of OMW were generated per ton of processed olives, while currently an average-sized modern olive oil factory leads to a sensibly higher amount of effluents, up to $10-15 \mathrm{~m}^{3}$ daily, combining OWW and OMW (Mendoza et al., 1996). Taking into account the case of Spain, the main olive oil producer worldwide, this raises a total volume of more than 9 million $\mathrm{m}^{3}$ of OMW per year, which represents a huge amount of this highly pollutant effluent (Martínez-Nieto et al., 2008).

In the two-phase olive oil extraction system, water injection is only practiced in the final vertical centrifugation step, and thus the volume of liquid effluent produced (OMW2) is reduced by one third on average if compared to the amount required for the three-phase system (OMW3).

The two-phase system appears to be more ecological. For this reason, this system has been strongly promoted in Spain. Otherwise, the threephase system is still surviving in other countries where scarcity of financial support has not yet permitted this technological switch. Purification of the effluents from both decanting processes is specifically addressed as a hard task given their highly variable physico-chemical compositions, which also depend on edaphoclimatic and cultivation parameters, the type, quality and maturity of the olives (Paraskeva and Diamadopoulos, 2006; Hodaifa et al., 2013a).

OMW are among the heaviest polluted industrial effluents and are typically characterized by strong odor nuisance, acidic $\mathrm{pH}$, intense dark-violet color and high saline toxicity, which is reflected by considerable electro conductivity (EC) values (Hodaifa et al., 2013a; Martínez-Nieto et al., 2011 a; Ochando-Pulido et al., 2012, 2013a, 2013b). Uncontrolled disposal of these effluents represents an important environmental issue because it causes severe soil contamination, underground leakage and water pollution (Hodaifa et al., 2013a; Martínez-Nieto et al., 2011a).

Major organic pollutant concentration is found in the effluent from the centrifuges, including mainly phenolic compounds, organic acids, tannins and organo-halogenated contaminants which are mostly phytotoxic and recalcitrant to biological degradation. The presence of these substances is hardly reflected by measurements of the biological oxygen demand $\left(\mathrm{BOD}_{5}\right)$; therefore the chemical oxygen demand (COD) seems to be more appropriate as a key parameter together with the total phenolic compound (TPh) concentration (Hodaifa et al., 2013a; Paraskeva and Diamadopoulos, 2006).

Because of the high levels of COD, refractory compounds, and also fats and lipids, direct disposal of these effluents into the municipal sewage treatment systems is forbidden. However, at the moment there is no specific European legislation concerning the regulation of olive mill discharges, and standard procedures are delegated to individual countries. In spite of this fact, EU has a directive, Directive 2000/60/CE, pointing out the necessity for conferring maximum protection to water and introducing the idea of the use of regenerated wastewater and thus encouraging the establishment of a legal framework capable of achieving this goal. Therefore, direct discharge of OMW onto ground fields and public superficial waters is actually prohibited in Spain; this is not the case of other EU countries where partial discharge onto suitable terrain is still allowed, such as in Italy and Portugal.

A wide range of reclamation procedure practices and combined treatments for OMW has already been proposed and developed (Borja et al., 2006), such as lagooning or natural evaporation and thermal concentration (Paraskeva and Diamadopoulos, 2006), composting (Cegarra et al., 1996), treatments with clay (Al-Malah et al., 2000) or with lime (Aktas et al., 2001), biological processes (Ena et al., 2007;), physico-chemical procedures including coagulation-flocculation (Sarika et al., 2005; Stoller, 2011), electro coagulation (Tezcan et al., 2006) and biosorption (Hodaifa et al., 2013a), advanced oxidation processes including ozonation (Beltrán et al., 2000), Fenton's reaction (Martínez-Nieto et al., 2011a, 2011b; Hodaifa et al., 2013b) and photocatalysis (Sacco et al., 2012), electrochemical treatments (Inan et al., 2004) and hybrid processes (Grafias et al., 2010), but none has led to completely satisfactory results.

In our previous studies, the management of OMW for irrigation purposes by means of advanced chemical oxidation based on Fenton's reagent followed by flocculation-sedimentation and biosorption through olive stones was reported (Hodaifa et al., 2013a, 2013b).

The previous secondary depuration sequence based on Fenton's advanced oxidation process succeeded in overcoming the problem related to the presence of phenolic compounds and achieved a considerable chemical oxygen demand (COD), 
suspended solids and total phenol reduction (Hodaifa et al., 2013a, 2013b). However, the OMW2 effluent presented a significant conductivity after this process, owing mainly to dissolved monovalent and divalent ionic species, which cannot be removed by conventional physicochemical treatments.

In this regard, membrane technology is compact and modular, presents high efficiency and moderate investment and maintenance expenses (Akdemir and Ozer A., 2009; Ochando-Pulido et al., 2013a, 2013b; 2014). The biggest technical drawback for the implementation of membrane technologies in wastewater treatment plants is still membrane fouling (Stoller and Ochando, 2014 and 2015). Therefore, the optimal operation of membrane processes should be targeted to attain only the formation of reversible fouling in order to ensure constant performance over a long period of time. Specifically, membrane rejection selectivity can be shifted during the dynamic performance of the membrane module.

In this paper, the effect of the operating parameters on the dynamic membrane rejection performance towards the target inorganic species was examined and discussed. It is very important to emphasize that most of the existing studies on membranes only focus on punctual rejection efficiency values, which are not reliable at all, and do not evaluate the dynamic behavior of the membrane rejection selectivity, which always varies during operation time due to concentration polarization and fouling build-up on the membrane surface. The aim of this study was the final purification of the OMW2 effluent, to reduce its high inorganic species content, so as to achieve the standards that allow for reusing the effluent for irrigation purposes.

\section{MATERIALS AND METHODS}

\subsection{Effluent feedstock}

Olive mill effluent samples (OMW) were gathered from various olive oil mills in the Andalusian provinces of Jaén and Granada (Spain) during the winter months, after which they were rapidly analyzed in the lab and refrigerated for further research.

Before the beginning of the experiments, OMW was submitted to a secondary treatment on a pilot scale based on a Fenton-like advanced oxidation process, as described in detail in previous works by the Authors (Martínez-Nieto et al., 2011a, 2011b; Hodaifa et al., 2013a, 2013b). The OMW effluent after the secondary treatment (OMW2) will be hereafter subjected to the final membrane operation.

\subsection{Membrane plant}

The membrane plant used for the experiments was a bench-scale one (Prozesstechnik $\mathrm{GmbH}$ ), which comprised of a plate-and-frame module (Figure 1). Flat-sheet RO membranes (supplied by GE Water and Process Technologies) were selected for the experiments, and presented the characteristics reported in Table 1.

The membrane plant consisted of a non-stirred double walled tank (5 L) and a diaphragm pump (Hydra-Cell, model D-03) which could be adjusted to drive the effluent stream to a plate-and-frame membrane module M1 (dimensions $3.9 \mathrm{~cm}$ width x 33.5 $\mathrm{cm}$ length). The plant was also equipped with another different membrane module (M2), which could be either a spiral-wound or tubular one, and could be switched by means of a three-way valve (V6).

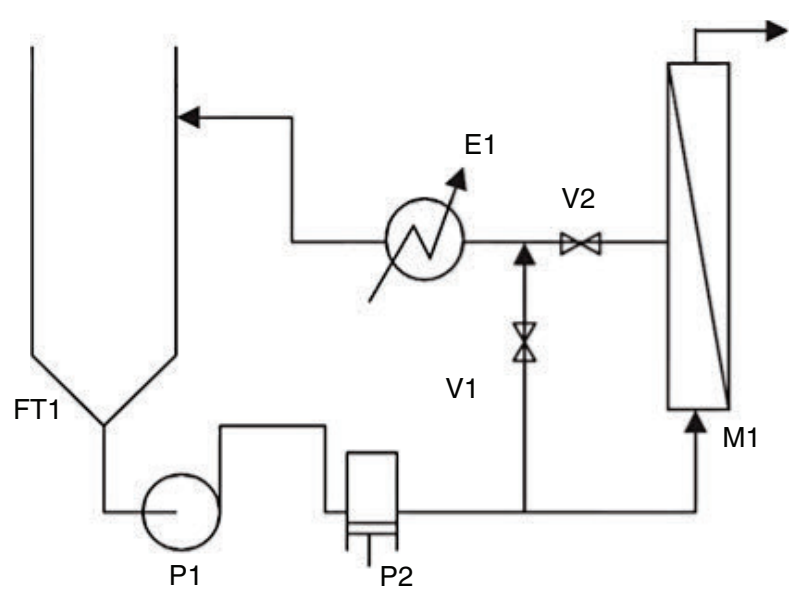

FIGURE 1. Flow diagram of the RO membrane pilot plant, FT1 feedstock tank (100 L), P1: booster pump, P2: volumetric pump, V1: bypass regulation valve (precision $0.5 \mathrm{bar}$ ), V2: concentrate regulation valve (precision $10 \mathrm{Lh}-1$ ), E1: plate heat exchanger, M1: membrane housing provided with $\mathrm{RO}$ membrane.

TABLE 1. Characteristics of the selected virgin membranes

\begin{tabular}{|c|c|}
\hline Parameters & \\
\hline Membrane type & RO \\
\hline Manufacturer & GE (USA) \\
\hline Model series & $\mathrm{SC}$ \\
\hline Measured permeability $\left(\mathrm{m}_{0}\right), \mathrm{L} / \mathrm{hm}^{2}$ bar & $1.5 \pm 0.2$ \\
\hline Configuration & Flat-sheet \\
\hline Chemical composition & $\mathrm{TFC}^{\mathrm{c}} \mathrm{PA}^{\mathrm{a}} / \mathrm{PS}^{\mathrm{b}}$ \\
\hline Average pore size, $\mathrm{nm}$ & - \\
\hline${ }^{\mathrm{d}} \mathrm{MWCO}, \mathrm{Da}$ & - \\
\hline Maximum pressure, bar & 40 \\
\hline Maximum temperature, ${ }^{\circ} \mathrm{C}$ & 50 \\
\hline
\end{tabular}

${ }^{\mathrm{a}} \mathrm{PA}$ : polyamide; ${ }^{\mathrm{b}} \mathrm{PS}$ : polysulfone; ${ }^{\mathrm{c}} \mathrm{TFC}$ : thin-film composite; MWCO: molecular weight cut-off. 
The principal process parameters (operating pressure, temperature and feed flow rate) were measured and displayed in-situ. The operating pressure could be finely set with a spring loaded pressure-regulating valve (SS-R4512MM-SP, Swagelok) placed on the concentrate outlet and monitored by a digital pressure gauge (Endress+Hauser, model Ceraphant T PTC31), thus allowing independent control of the operating pressure $\left(\mathrm{P}_{\mathrm{TM}}\right.$ set point \pm 0.01 bar $)$ and the flow rate; the feed flow rate was regulated by means of a feed flow rate valve $\left(\mathrm{F}_{\text {set point }} \pm 0.1 \mathrm{~L} / \mathrm{h}\right)$ to fix the tangential velocity over the membrane (Mott and Untener, 2014); the operating temperature was regulated automatically $\left(\mathrm{T}_{\text {setpoint }} \pm 0.1^{\circ} \mathrm{C}\right)$ by means of a proportional-integral-derivative (PID) electronic temperature controller (Yokogawa, model UT100) and a magnetic valve in the cooling loop, which recirculated cooling water from a chiller (PolyScience model 7306) inside the tank's refrigeration jacket.

The system was also automatically protected in the case of over-pressure or over-temperature. All medium wetted metallic parts were made of corrosion-resistant stainless steel $316 \mathrm{~L}$, except for the permeate and concentrate stream outlet tubes, which were made of chemical-resistant polyethylene.

\subsection{RO membrane module performance: a focus on the dynamic rejection efficiency}

Prior to each RO experiment, the corresponding membrane coupon was stabilized by filtration with MilliQ ${ }^{\circledR}$ water at a fixed pressure and temperature until a constant and stable flux was observed. After this, the hydraulic permeability $\left(\mathrm{m}_{0}\right)$ of the selected membrane coupon was determined by measuring the pure water flux over its admissible applied pressures range (see Table 1), at ambient temperature and turbulent cross-flow velocity.

Subsequently, 2L of OMW2 effluent were poured into the feed water tank to proceed with the membrane purification operation. Bench-scale RO experiments were run in a dynamic semi-continuous mode, conducted at ambient temperature $\left(22 \pm 0.1^{\circ} \mathrm{C}\right)$ and upon tangential-flow turbulent regime over the membrane. The effect of the operating parameters comprising the operating pressure (15-35 bar) and feed flow rate $(3 \mathrm{~L} / \mathrm{min}-6 \mathrm{~L} / \mathrm{min}$, corresponding to cross-flow velocity from $2.55-5.09 \mathrm{~m} / \mathrm{s}$ ) on the membrane rejection performance towards the target inorganic species was examined.

The operating procedure consisted of continuously recycling the concentrate stream back to the feed water tank while steadily collecting the permeate stream, which was replaced by the same volume of fresh pretreated OMW2. This semi-continuous mode, also known as diafiltration, is intended for the maximum recovery of the feed stream volume (minimum $80 \%$ ). Periodically, samples of the permeate stream were collected in a cumulative vessel and analyzed in order to evaluate the membrane separation effectiveness with respect to conductivity and ionic species rejection. The membrane productivity was also assayed by measuring the permeate flux during operation time by weighing the mass of collected permeate on a precision electronic mass balance (AX -120 Cobos, $0.1 \mathrm{mg}$ accuracy).

The membrane performance was measured in terms of permeate flux and solute rejection. The observed rejection towards the target ionic species as well as conductivity, were calculated as follows:

$$
R_{i}(\%)=\left(1-\left(c_{p, i} / c_{f, i}\right)\right) \times 100
$$

where $c_{p, i}$ is the concentration of the solute $i$ in the permeate stream, and $c_{f, i}$ the concentration of the solute $i$ in the feed water tank.

After each semi-batch run, the membrane was recovered for the following experiment by cleaning it in situ with $0.1-0.15 \% \mathrm{w} / \mathrm{v} \mathrm{NaOH}$ and $0.1-0.15 \%$ w/v sodium dodecyl sulfate (SDS) solutions (provided by Panreac S.A.), as reported in a previous work by the Authors (Ochando-Pulido, 2015).

\subsection{Analytical procedures}

All the analyses were carried out in triplicate with analytical-grade reagents. Chemical oxygen demand (COD), total phenols (TPh), total iron, total suspended solids (TSS), electro conductivity (EC) and $\mathrm{pH}$ were measured following standard methods (Greenberg et al., 2005).

Ionic concentrations in the inlet stream and the permeate outlet were analyzed with a Dionex DX-120 ion chromatograph. Primarily, pre-filtration of the feed water (previously diluted 1/10) and permeate samples through a $22 \mu \mathrm{m}$ cellulose acetate filter was conducted in order to avoid impurities entering the chromatograph. The chromatograph was equipped with IonPac AG9-HC and IonPac $\mathrm{CS} 12 \mathrm{~A}$ anionic and cationic columns respectively, whereas suppression for cations and anions was determined with ASRS-300 (4 mm) and CSRS-300 (4 mm) self-regeneration suppressors, respectively. To avoid small air bubbles entering the chromatograph loop, the eluent solution was filtered and sonicated before each set of analyses. Eluent flow rate was fixed at $1 \mathrm{~mL} / \mathrm{min}$ and pressures for anionic and cationic analyses were 135 bar and 64 bar, respectively. The eluent buffer solutions used for anionic and cationic analyses $\left(9 \mathrm{mM} \mathrm{NaHCO} / \mathrm{Na}_{2} \mathrm{CO}_{3}\right.$ and $20 \mathrm{mM}$ MSA respectively) were provided by Sigma Aldrich (Fluka), in addition to the standard solutions used to determine the cationic and anionic straight patterns. Chromatographic data analyses were conducted on the PeakNet 5.1 software. 


\section{RESULTS AND DISCUSION}

\subsection{Physicochemical composition of OMW prior to membrane process}

The physicochemical composition of the pretreated OMW2 stream, given in Table 2, reveals a high conductivity (EC) mainly due to the significant concentration of sodium and chloride ions, as a result of the use of sodium hydroxide and ferric chloride catalyst in the previous advanced oxidation process (Hodaifa et al., 2013a).

The goal of the present study was to experimentally evaluate the feasibility of a further treatment of the effluent exiting the Fenton-like process by means of RO technologies on a preliminary lab scale. For this reason, pre-treated OMW was conducted through a final purification step by means of a TFC polyamide/polysulfone RO membrane for the removal of this highly remaining EC. The intention was to achieve the suitability for re-using the final effluent in the olive oil production process and therefore close the loop.

\subsection{Rejection performance of the selected RO membrane towards inorganic solutes}

During the course of the OMW2 RO semicontinuous purification experiments, the dynamic rejection efficiency towards the target ionic species comprising monovalent (chloride, nitrate) and divalent (sulfate) anions present in the effluent, as well as monovalent (sodium, potassium) and divalent

TABLE 2. Physicochemical composition of secondarytreated OMW

\begin{tabular}{lc}
\hline Parameters & Parametric value \\
\hline $\mathrm{pH}$ & $8.0 \pm 0.2$ \\
Conductivity, mS/cm & $4.5 \pm 1.0$ \\
Total suspended solids, mg/L & $15.0 \pm 1.0$ \\
$\mathrm{COD}, \mathrm{mg} / \mathrm{L}$ & $173.5 \pm 53.0$ \\
Total phenols, $\mu \mathrm{g} / \mathrm{L}$ & $685 \pm 295$ \\
Total iron, $\mu \mathrm{g} / \mathrm{L}$ & $700 \pm 300$ \\
{$\left[\mathrm{~F}^{-}\right], \mathrm{mg} / \mathrm{L}$} & $2.1 \pm 0.2$ \\
{$\left[\mathrm{Cl}^{-}\right], \mathrm{mg} / \mathrm{L}$} & $960.4 \pm 84.6$ \\
{$\left[\mathrm{Br}^{-}\right], \mathrm{mg} / \mathrm{L}$} & $2.3 \pm 0.4$ \\
{$\left[\mathrm{NO}_{3}{ }^{-}\right], \mathrm{mg} / \mathrm{L}$} & $8.0 \pm 0.6$ \\
{$\left[\mathrm{SO}_{4}{ }^{2-}\right], \mathrm{mg} / \mathrm{L}$} & $133.3 \pm 6.0$ \\
{$\left[\mathrm{HCO}_{3}\right], \mathrm{mg} / \mathrm{L}$} & $131.1 \pm 1.8$ \\
{$\left[\mathrm{PO}_{4}{ }^{-}\right], \mathrm{mg} / \mathrm{L}$} & $1.9 \pm 1.3$ \\
{$\left[\mathrm{Na}^{+}\right], \mathrm{mg} / \mathrm{L}$} & $317.6 \pm 97.3$ \\
{$\left[\mathrm{~K}^{+}\right], \mathrm{mg} / \mathrm{L}$} & $53.5 \pm 12.0$ \\
{$\left[\mathrm{Ca}^{2+}\right], \mathrm{mg} / \mathrm{L}$} & $93.9 \pm 9.9$ \\
{$\left[\mathrm{Mg}^{2+}\right], \mathrm{mg} / \mathrm{L}$} & $27.0 \pm 5.6$ \\
\hline
\end{tabular}

(calcium, magnesium) cations, was followed and examined as a function of the different operating parameters. It is important to point out that most of the existing studies on membranes only focus on punctual rejection efficiency values, which are not reliable at all, and do not evaluate the dynamic behavior of the membrane rejection selectivity, which always varies during operation time due to concentration polarization and fouling build-up on the membrane surface.

The rejection efficiencies of monovalent anions - chloride (panel A), nitrate (panel B) and sulfate (panel $C$ ) - is comparatively reported in Tables 3 and 4, respectively. A similar pattern was found for the monovalent and divalent cations, as shown in Figures 2 and 3. Otherwise, the rejection of both divalent cations and anions remained invariably constant at over $99 \%$ regardless of the operating conditions.

A comparison of the EC rejection efficiency in the permeate stream during the course of the RO experiments under different operating conditions is reported in Figure 4. The EC of electrolytic solutions depends on the concentration of the ionic species and also on their nature, that is, their charge and mobility.

The charge of the polymer material is believed to influence salt transport in sulfonated polymers used for de-salination applications, such as the TFC polyamide/polysulfone one selected by influencing ion

TABLE 3. Rejection of anionic species by the RO membrane as a function of the operating pressure.

\begin{tabular}{lcc}
\hline Species & Pressure (bar) & Rejection (\%) \\
\hline $\mathrm{Cl}^{-}$ & 15 & $97.7 \pm 0.4$ \\
& 25 & $98.5 \pm 0.2$ \\
& 35 & $99.1 \pm 0.2$ \\
$\mathrm{SO}_{4}{ }^{2-}$ & 15 & $90.0 \pm 0.5$ \\
& 25 & $91.3 \pm 0.3$ \\
& 35 & $92.3 \pm 0.1$ \\
$\mathrm{NO}_{3}{ }^{-}$ & 15 & $98.6 \pm 0.2$ \\
& 25 & $99.0 \pm 0.1$ \\
& 35 & $99.3 \pm 0.1$ \\
\hline
\end{tabular}

TABLE 4. Rejection of anionic species by the RO membrane as a function of the tangential velocity $\left(\mathrm{v}_{\mathrm{t}}\right)$

\begin{tabular}{lcc}
\hline Species & $\mathbf{v}_{\mathbf{t}}, \mathbf{m} / \mathbf{s}$ & Rejection, \% \\
\hline $\mathrm{Cl}^{-}$ & 2.55 & $98.6 \pm 0.2$ \\
& 5.09 & $98.2 \pm 0.3$ \\
$\mathrm{SO}_{4}{ }^{2-}$ & 2.55 & $91.3 \pm 0.2$ \\
& 5.09 & $91.0 \pm 0.5$ \\
$\mathrm{NO}_{3}{ }^{-}$ & 2.55 & $99.0 \pm 0.1$ \\
& 5.09 & $98.9 \pm 0.1$ \\
\hline
\end{tabular}


(a)

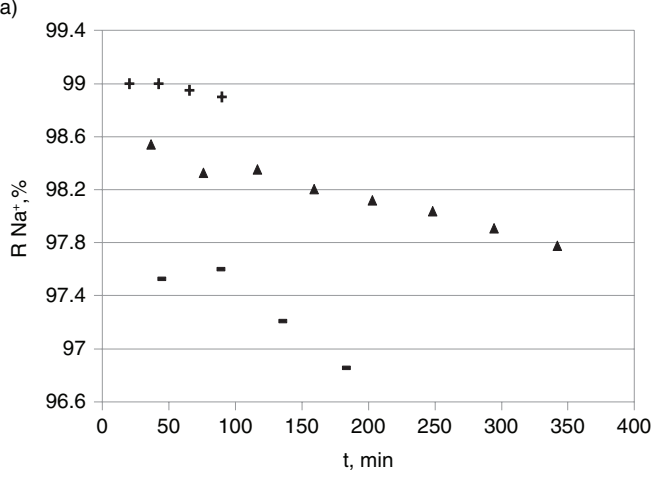

(b)

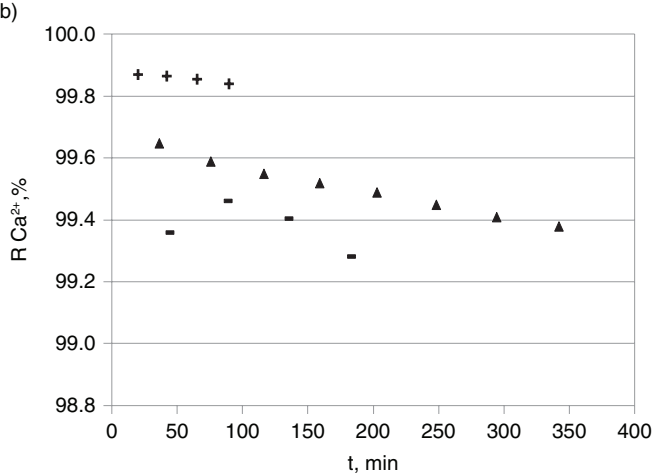

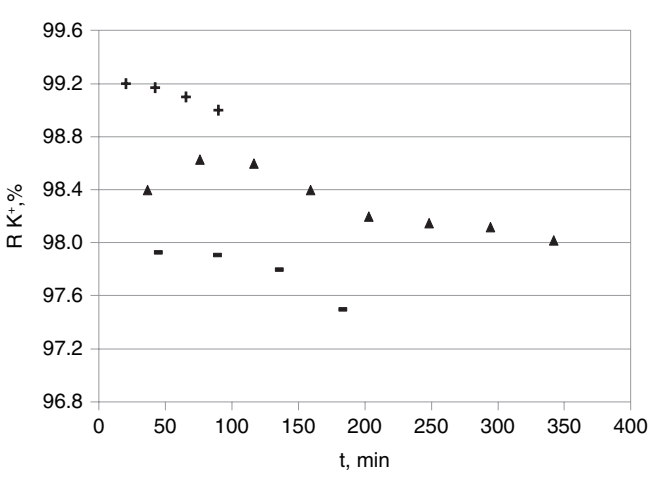

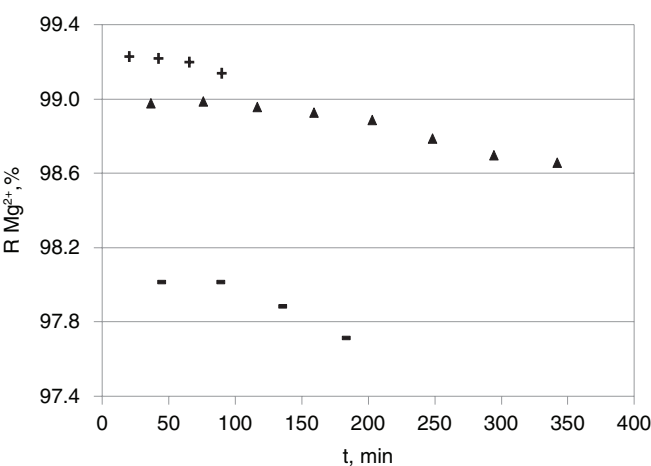

FIGURE 2. Effect of the net operating pressure (15-35 bar) on the rejection efficiency towards monovalent cations in OMW2 sodium (panel A), potassium (panel B) - and divalent ones - calcium (panel A), magnesium $\left(\right.$ panel B). $22^{\circ} \mathrm{C}, 2.55 \mathrm{~m} / \mathrm{s}$ : $+=35 \mathrm{bar}$; $\mathbf{\Delta}=25$ bar; $-=15$ bar.
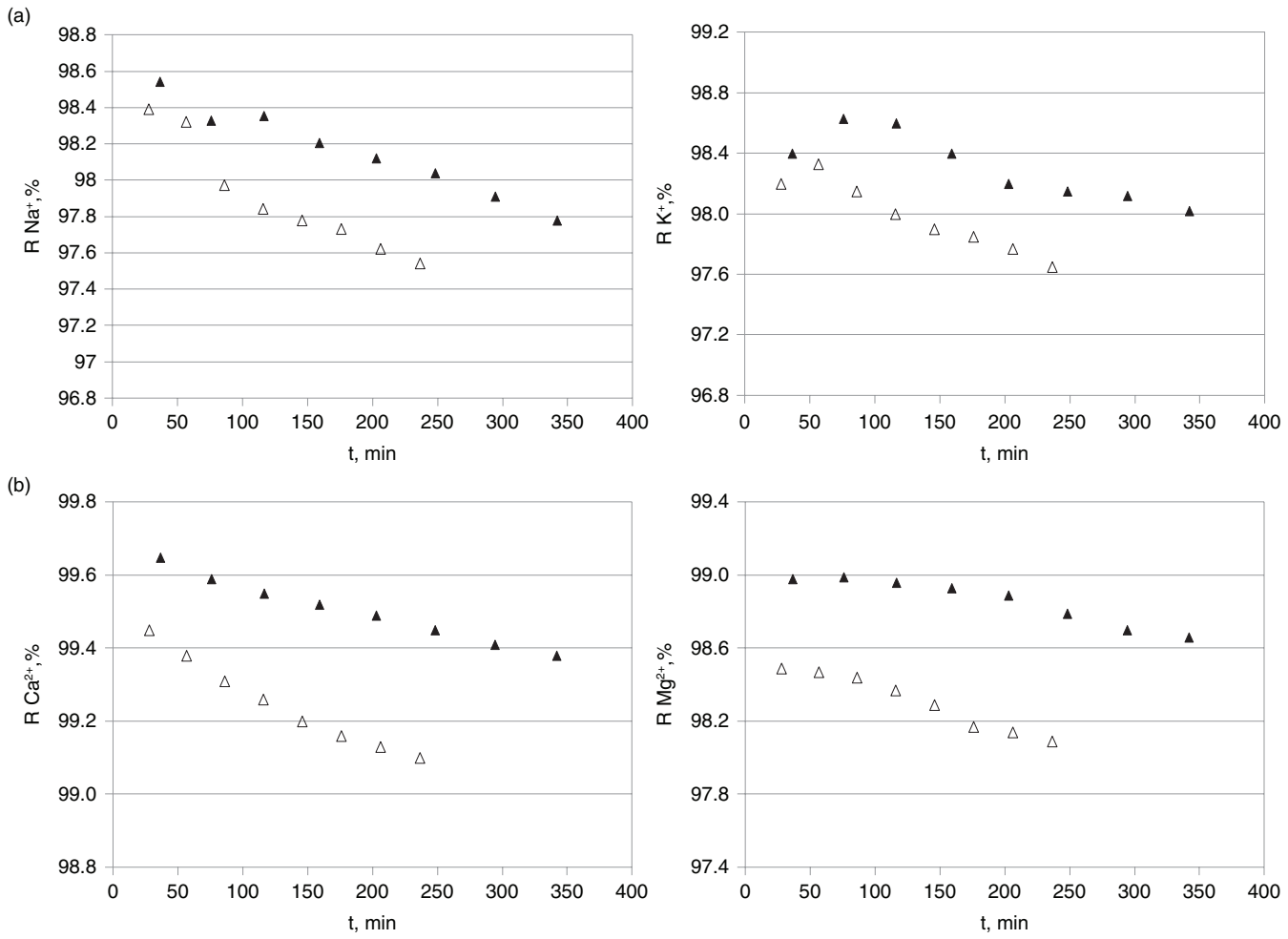

FIGURE 3. Effect of cross flow velocity $(2.55-5.09 \mathrm{~m} / \mathrm{s})$ on the rejection efficiency towards monovalent cations in OMW2 - sodium (panel A), potassium (panel B) - and divalent ones - calcium (panel A), magnesium (panel B) during RO operation time. $22^{\circ} \mathrm{C}$, 25 bar: $\boldsymbol{\Delta}=2.55 \mathrm{~m} / \mathrm{s} ; \Delta=5.09 \mathrm{~m} / \mathrm{s}$. 
(a)

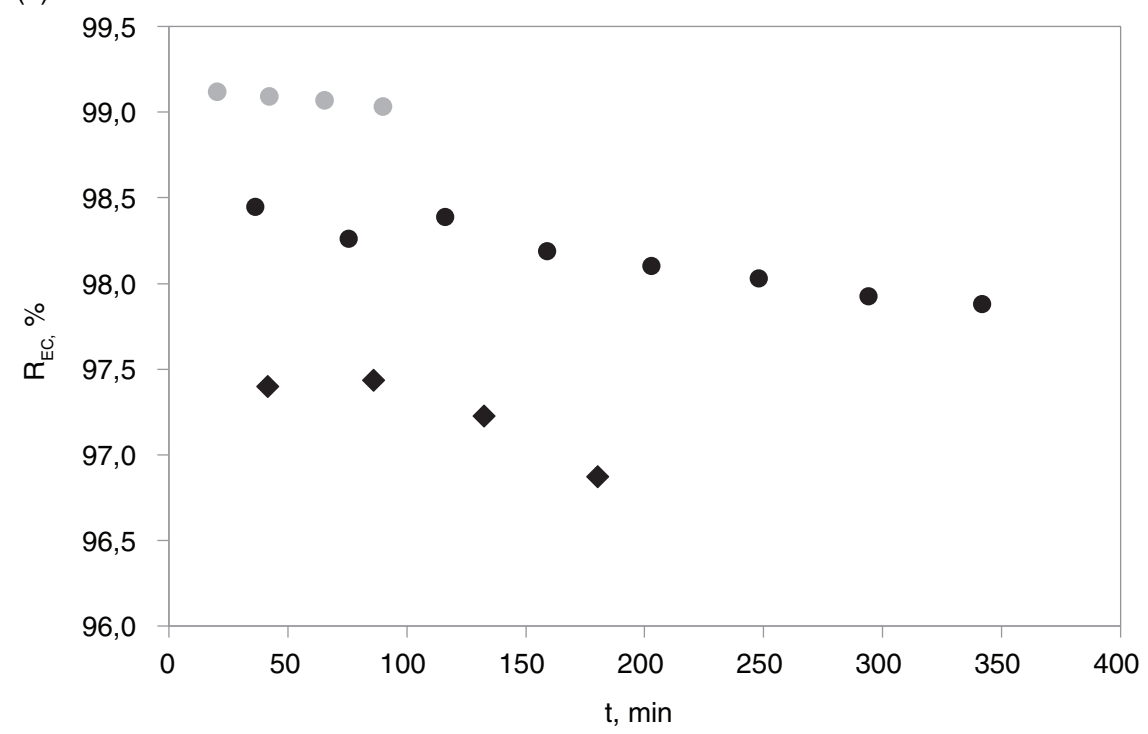

(b)

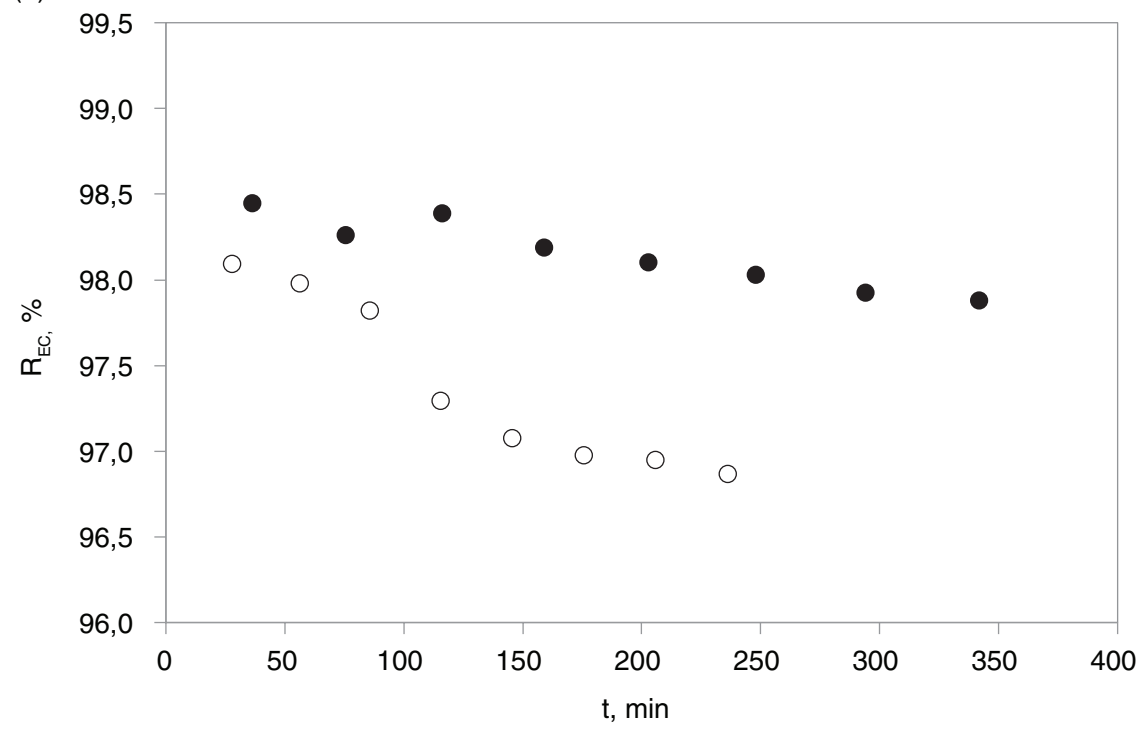

FIGURE 4. Effect on the rejection efficiency towards electroconductivity (REC) during RO operation time of: net operating pressure (15-35 bar) (panel A), $22^{\circ} \mathrm{C}, 2.55 \mathrm{~m} / \mathrm{s}: \bullet=35$ bar; $\bullet=25$ bar; $\bullet 15$ bar; cross flow velocity $(2.55-5.09 \mathrm{~m} / \mathrm{s}), 22^{\circ} \mathrm{C}, 25$ bar: $\bullet=2.55 \mathrm{~m} / \mathrm{s} ; \mathrm{o}=5.09 \mathrm{~m} / \mathrm{s}$.

absorption into and diffusion through the polymer. However, the extent to which this effect can be leveraged to prepare materials with high salt rejection is not yet fully understood (Geise et al., 2010).

The rejection efficiencies of all anionic and cationic species were observed to follow a similar pattern, which consisted of a slight improvement during the first minutes of operation in all the experiments which further decreased over time. This can be explained as a result of the increasing concentration of ions in the bulk during semi-continuous RO membrane operation, which leads to an increasing concentration gradient in the vicinity of the membrane boundary layer. This leads to an osmotic pressure increment in the bulk side of the membrane, owing to a combination of hindered back-diffusion of ions and altered cross flow hydrodynamics within the accumulated deposits on the membrane's active surface. As a result, the enhanced concentration polarization layer triggers ion passage (Hoek and Elimelech, 2003). These results are supported by the mirrored behavior measured for the EC values in the permeate stream, as can be observed in the data reported in Figure 4.

The effect of the main RO membrane operating parameters comprising the net operating pressure (15-35 bar) and the feed flow rate $(3 \mathrm{~L} / \mathrm{min}-6 \mathrm{~L} / \mathrm{min}$, corresponding to cross flow velocity from $2.55-5.09 \mathrm{~m} / \mathrm{s}$ ) 
on the membrane rejection performance towards the target inorganic species was further examined.

A guided focus on these gathered data (Tables 2-3 and Figures 2-3) highlights increased rejection efficiency values towards the target ionic species upon an increase of the net operating pressure. This can be attributed to the fact that water flux is enhanced while similar ion diffusivity is attained, resulting in dilution in the permeate (Feini et al., 2008; Jae-Wook Lee et al., 2006). Charged polymers are often characterized by their counter-ion form. An acidic form polymer is one where the counter-ions are protons. Ion exchange processes govern the polymer's counterion form. As stated by Geise et al. (2010) the concentration of mobile salt in a cation exchange polymer is characterized by the concentration of anions absorbed in the polymer, because a salt pair $\left(\mathrm{M}^{+} \mathrm{X}^{-}\right)$ must contain an anion to transport through the cation exchange polymer, which contains an excess of cations. In contrast, in uncharged polymers, the concentration of mobile salt is characterized by the concentration of either cations or anions.

On the contrary, minor ionic rejection was measured when the cross flow velocity was incremented. A turbulent regime over the membrane surface was already ensured in the lower flow rate set-up. Therefore, it seemed that given that improved shear rate partially swept away the cross-linked fouling layer performing as an added resistance, the permeate flux was enhanced but ion passage might not be so tightly hindered.

The increase in cross flow promotes a higher turbulence near the membrane active layer, which is measured as the Reynolds number increases from $N_{R e} 1.3 \cdot 10^{4}$ to $2.6 \cdot 10^{4}$. As a consequence, concentration polarization and the formation of a fouling layer are minimized, and an increase in the cross flow has a marked beneficial effect on fouling reduction. An inverse behavior has been reported for wastewater with significant conductivity but very low organics by Jae-Wook Lee et al. (2006). Moreover, it should not be disregarded that some ionic species such as calcium ions - tend to promote intra- and inter-molecular bridge formation and aggregation of organic matter (Lee et al., 2006; Peng et al., 2003). Hence, the suspended and colloidal organic matter still present in the pre-treated OMW2 stream might adsorb certain monovalent and divalent cations, leading to the formation of large aggregates that could be more easily retained by the membrane. This fact would be therefore shielded at very high tangential velocity.

To sum up briefly, rejection efficiencies for the three anions were noticed to follow the order $\mathrm{SO}_{4}{ }^{2-}>\mathrm{Cl}^{-}>\mathrm{NO}_{3}{ }^{-}$whereas the cationic species fitted the trend $\mathrm{Ca}^{2+}>\mathrm{Mg}^{2+}>\mathrm{K}^{+}>\mathrm{Na}^{+}$, as a rule and with no regard to the operating conditions. This is in good agreement with ion-exchange selectivity data published by Mukherjee et al. (2003) and other membrane-field researchers (Jae-Wook Lee et al., 2006; Feini et al., 2008). Theoretically, a ion exchange selectivity for a specific ion represents a smaller hydrated ionic radius, which in turn leads to a greater inter-diffusion coefficient or so-called salt permeability coefficient. The latter fact provides an explanation for the permeability order of homovalent ions observed (Mukherjee et al., 2003).

Divalent cations and also divalent anions were moderately more highly rejected than monovalent ones, in accordance with their higher charge and molecular size. Sulfate anions were consistently rejected by over $99 \%$ (meaning that the concentrations measured in the permeate stream were below $1 \mathrm{ppm}$ ), whereas chloride and nitrate anions showed very slightly lower rejection (see Tables 3 and 4). This was the same case for the rejection of calcium and magnesium with respect to their monovalent homologous (sodium and potassium) (see Figures 2 and 3 ).

On the other hand, iron $\left(\mathrm{Fe}^{3+}\right)$ ions were found to be completely rejected during the course of all the RO experiments, regardless of the operating conditions set-up, whereas the concentration of other ions in the permeate stream was negligible.

It should be pointed as well that the rejection efficiencies observed for the anionic species were somehow greater than the cationic ones (around $1 \%$ ). This is based on the fact of the overall permeation rate being controlled by the anion diffusivity since the membrane surface has a negative charge, and thereby, there is an electric potential (Donnan potential) established between the membrane and the bulk solution. This electrical potential, named the Donnan exclusion, is responsible for the rejection of the co-ion (i.e. anions) from the membrane (Seidel et al., 2001).

Salt absorption in uncharged polymers takes place by a simple partitioning mechanism whereby ions absorb into the polymer matrix as mobile salt, which means that each equivalent of absorbed cations is accompanied by an equivalent of absorbed anions to maintain electro-neutrality within the film. On the other hand, ion absorption in a charged polymer proceeds by both ion exchange and simple partitioning mechanisms (Geise et al., 2010). Electro-neutrality must be maintained, therefore fixed charge groups associate with counter-ions. Cations act as counter-ions to both the fixed charge groups (sulfonated functional groups) as well as the absorbed anions $\left(\mathrm{X}^{-}\right)$. Therefore, cation exchange polymers generally absorb more cations than anions on an equivalent basis. This difference in anion and cation concentration in the polymer is balanced electro-statically by the polymer's fixed charge groups, previously referred to as the Donnan exclusion (Geise et al., 2014).

The previous secondary depuration sequence based on Fenton's advanced oxidation process 
succeeded in overcoming the problem related to the presence of phenolic compounds and achieved considerable chemical oxygen demand (COD), suspended solids and total phenol reduction (Hodaifa et al., 2013a,2013b). However, the OMW2 effluent presented a significant conductivity after this process, owing mainly to dissolved monovalent and divalent ionic species, which could not be removed by conventional physicochemical treatments. Finally, the RO membrane exiting the treated effluent was depleted of the high EC values initially present (rejection by above $97 \%$ ), that is, of the target ionic species, permitting its re-use in the olive fields as good quality irrigation water following the FAO recommendations (2003) (EC below $1 \mathrm{mS} / \mathrm{cm}$ ).

\section{CONCLUSIONS}

In previous works on olive mill wastewater (OMW), secondary advanced oxidation treatment ensured the removal of its high organic matter concentration, including phenolic compounds. Nevertheless, the effluent presented a significant salinity after this process, owing mainly to dissolved monovalent and divalent ionic species as a result of the use of sodium hydroxide and ferric chloride catalyst.

In the present study, the adequate operation of a reverse osmosis (RO) membrane is examined to ensure constant performance over a long period of time. The effect of the operating parameters comprising the operating pressure and feed flow rate on the dynamic membrane rejection performance towards the target inorganic species was examined and discussed. The aim was the final purification of the OMW2 effluent, to reduce its high inorganic species content, so as to achieve the standards that permit re-using the effluent for irrigation purposes.

The rejection efficiencies of all anionic and cationic species were observed to follow a similar pattern, which consisted of a slight improvement during the first minutes of operation in all the experiments which further decreased over time. Rejection of both divalent cations and anions remained invariably constant at over $99 \%$ regardless of the operating conditions. To sum up, rejection efficiencies were noticed to follow the order $\mathrm{SO}_{4}{ }^{2-}>\mathrm{Cl}^{-}>\mathrm{NO}_{3}^{-}$whereas $\mathrm{Ca}^{2+}>\mathrm{Mg}^{2+}>\mathrm{K}^{+}>\mathrm{Na}^{+}$, as a rule. Divalent species were moderately more highly rejected than monovalent ones, in accordance with their higher charge and molecular size, and sulfate anions were consistently rejected at over $99 \%$.

Finally, the exiting treated effluent was depleted of the high EC values initially present, that is, of the target ionic species, permitting its re-use as irrigation water in the olive fields.

\section{ACKNOWLEDGMENTS}

The Spanish Ministry of Science and Innovation and Ministry of Economy and Competitiveness are gratefully acknowledged for having funded respectively the projects CTQ2010-21411 and CTM201461105-JIN, as well as the University of Granada.

\section{REFERENCES}

Akdemir E O, Ozer A. 2009. Investigation of two ultrafiltration membranes for treatment of olive oil mill wastewater. Desalination 249, 660-666. http://dx.doi.org/10.1016/j. desal.2008.06.035

Aktas ES, Imre S, Esroy L. 2001. Characterization and lime treatment of olive mill wastewater. Water Res. 35, 2336-2340. https://doi.org/10.1016/S0043-1354(00)00490-5

Al-Malah K, Azzam MOJ, Abu-Lail NI. 2000. Olive mills effluent wastewater post-treatment using activated clay. Sep. Purif. Technol. 20, 225-234. http://dx.doi.org/10.1016/ S1383-5866(00)00114-3

Beltrán J, Torregrosa J, García J, Domínguez JR. 2000. Ozone treatment of olive mill wastewater. Grasas Aceites 51, 32-46. http://dx.doi.org/10.3989/gya.2000.v51.i5.428

Borja R, Raposo F, Rincón B. 2006. Treatment technologies of liquid and solid wastes from two-phase olive oil mills. Grasas Aceites 57, 32-46. http://dx.doi.org/10.3989/gya.2006.v57.i1.20

Cegarra J, Paredes C, Roig A, Bernal MP, García D. 1996. Use of olive mill wastewater compost for crop production. Int. Biodet. Biodegrad. 38, 193-203. http://dx.doi.org/10.1016/ S0964-8305(96)00051-0

Ena A, Carlozzi P, Pushparaj B, Paperi R, Carnevale S, Sacchi A. 2007. Ability of the aquatic fern Azolla to remove chemical oxygen demand and polyphenols from olive mill wastewater. Grasas Aceites 58, 32-46. http://dx.doi.org/10.3989/ gya.2007.v58.i1.6

Food and Agricultural Organization (FAO). 2003. Review of world water resources by country, Water Reports 23, Rome, Italy. ISBN 92-5-104899-1.

Feini L, Guoliang Z, Qin M, Hongzi Z. 2008. Performance of nanofiltration and reverse osmosis membranes in metal effluent treatment. Chinese J. Chem. Eng. 16, 441-445. http://dx.doi.org/10.1016/S1004-9541(08)60102-0

Geise GM, Lee HS, Miller DJ, Freeman BD, McGrath JE, Paul DR. 2010. Water purification by membranes: the role of polymer science. J. Polym. Sci., Part B Polym. Phys. 48, 1685-718.http://dx.doi.org/10.1002/polb.22037

Geise M, Donald RP, Freeman BD. 2014. Fundamental water and salt transport properties of polymeric materials. Progress in Polymer Sci. 39, 1-42. http://dx.doi. org/10.1016/j.progpolymsci.2013.07.001

Grafias P, Xekoukoulotakis NP, Mantzavinos D, Diamadopoulos E. 2010. Pilot treatment of olive pomace leachate by vertical-flow constructed wetland and electrochemical oxidation: an efficient hybrid process. Water Res. 44, 2773-2780. http://dx.doi.org/10.1016/j.watres.2010.02.015

Greenberg AE, Clesceri LS, Eaton AD. 2005. Standard Methods for the Examination of Water and Wastewater, APHA/ AWWA/WEF, 22th ed., Washington DC. Cabs.

Hodaifa G, Ochando-Pulido JM, Rodriguez-Vives S, MartinezFerez A. 2013a. Optimization of continuous reactor at pilot scale for olive-oil mill wastewater treatment by Fentonlike process. Chem. Eng. J. 220, 117-124. http://dx.doi. org/10.1016/j.cej.2013.01.065

Hodaifa G, Ochando-Pulido JM, Ben-Driss-Alami S, RodriguezVives S, Martinez-Ferez A. 2013b. Kinetic and thermodynamic parameters of iron adsorption onto olive stones. Ind. Crops Prod. 49, 526-534. http://dx.doi.org/10.1016/j. indcrop.2013.05.039

Hoek EMV, Elimelech M. 2003. Cake-enhanced concentration polarization: a new fouling mechanism for salt-rejecting membranes. Environ. Sci. and Tech. 37, 5581-5588. http:// dx.doi.org/10.1021/es0262636 
Inan H, Dimoglo A, Şimşek H, Karpuzcu M. 2004. Olive oil mill wastewater treatment by means of electro-coagulation. Sep. Purif. Technol. 36, 23-31. http://dx.doi.org/10.1016/ S1383-5866(03)00148-5

Jae-Wook Lee, Tae-Ouk Kwon, Il-Shik Moon, 2006. Performance of polyamide reverse osmosis membranes for steel wastewater reuse. Desalination 189, 309-322. http:// dx.doi.org/10.1016/j.desal.2004.10.033

Lee S, Ang W S, Elimelech M. 2006. Fouling of reverse osmosis membranes by hydrophilic organic matter: implications for water reuse. Desalination 187, 313-321. http://dx.doi. org/10.1016/j.desal.2005.04.090

Martínez Nieto L, Jiménez MV, Hodaifa G, Vives SR, Casares, J.A G. 2008. Process for the depuration of waste waters, National Patent N. 2282 043, Oficina Española de Patentes y Marcas. ES 2282043 B1.

Martínez Nieto L, Hodaifa G, Rodríguez Vives S, Giménez Casares JA, Ochando J. 2011a. Flocculation-sedimentation combined with chemical oxidation process. Clean Soil, air, water 39, 949-955. http://dx.doi.org/10.1002/ clen. 201000594

Martínez Nieto L, Hodaifa G, Rodríguez Vives S, Giménez Casares JA Ochando J. 2011b. Degradation of organic matter in olive oil mill wastewater through homogeneous Fenton-like reaction. Chem. Eng. J. 173, 503-510. http:// dx.doi.org/10.1016/j.cej.2011.08.022

Mendoza A, Hidalgo-Casado F, Ruiz-Gómez MA, MartínezRomán F, Moyano-Pérez MJ, Cert-Ventulá A, Pérez-Camino MC, Ruiz-Méndez MV. 1996. Characteristics of olive oils from First and second centrifugation. Grasas Aceites 47, 163-181. http://dx.doi.org/10.3989/gya.1996.v47.i3.857

Mott R L, Untener J A, Applied Fluid Mechanics, $7^{\text {th }}$ edition, University of Dayton, 2014

Mukherjee P, Sengupta A K. 2003. Ion exchange selectivity as a surrogate indicator of relative permeability of ions in reverse osmosis processes. Environmental Sci. and Tech. 37, 1432-1440. http://dx.doi.org/10.1021/es0207495

Ochando-Pulido JM, Hodaifa G, Rodriguez-Vives S, MartinezFerez A. 2012. Impacts of operating conditions on reverse osmosis performance of pretreated olive mill wastewater. Water Res. 46, 4621-4632. http://dx.doi.org/10.1016/j. watres.2012.06.026

Ochando-Pulido JM, Hodaifa G, Victor-Ortega MD, RodriguezVives S, Martinez-Ferez A. 2013a. Effective treatment of olive mill effluents from two-phase and three-phase extraction processes by batch membranes in series operation upon threshold conditions. J. Hazard. Mater. 263, 168-176. http://dx.doi.org/10.1016/j.jhazmat.2013.03.041
Ochando-Pulido JM, Hodaifa G, Victor-Ortega MD, RodriguezVives S, Martinez-Ferez A. 2013b. Reuse of olive mill effluents from two-phase extraction process by integrated advanced oxidation and reverse osmosis treatment, $J$. Hazard. Mater. 263, 158-67. http://dx.doi.org/10.1016/j. jhazmat.2013.07.015

Ochando-Pulido JM, Hodaifa G, Victor-Ortega MD, MartinezFerez A. 2014. A novel photocatalyst with ferromagnetic core used for the treatment of olive oil mill effluents from two-phase production process. The Scientific World Journal. 2014. http://dx.doi.org/10.1155/2013/196470

Ochando-Pulido JM, Victor-Ortega MD, Martinez-Ferez A. 2015. On the cleaning procedure of a hydrophilic reverse osmosis membrane fouled by secondary-treated olive mill wastewater. Chem. Eng. J. 260, 142-151. http://dx.doi. org/10.1016/j.cej.2014.08.094

Paraskeva P, Diamadopoulos E. 2006. Technologies for olive mill wastewater (OMW) treatment: A review. J. Chem. Technol. Biotechnol. 81, 475-485. http://dx.doi.org/10.1002/jctb.1553

Peng W, Escobar I C, White DB. 2004. Effects of water chemistries and properties of membranes on the performance and fouling - a model development study. J. Memb. Sci. 238, 33-46. http://dx.doi.org/10.1016/j.memsci.2004.02.035

Sacco O, Stoller M, Vaiano V, Ciambelli P, Chianese A, Sannino D. 2012. Photocatalytic degradation of organic dyes under visible light on n-doped photocatalysts. Int. J. Photoenergy. http://dx.doi.org/10.1155/2012/626759

Sarika R, Kalogerakis N, Mantzavinos D. 2005. Treatment of olive mill effluents. Part II. Complete removal of solids by direct flocculation with poly-electrolytes. Environ. Int. 31, 297-304. http://dx.doi.org/10.1016/j.envint.2004.10.006

Stoller M. 2011. Effective fouling inhibition by critical flux based optimization methods on a NF membrane module for olive mill wastewater treatment. Chem. Eng. J. 168, 1140-1148. http://dx.doi.org/10.1016/j.cej.2011.01.098

Stoller M, Ochando-Pulido J.M., 2014. About merging threshold and critical flux concepts into a single one: the boundary flux. The Scientific World J. 2014, 656101. http:// dx.doi.org/10.1155/2014/656101

Stoller M, Ochando-Pulido J.M., 2015. The boundary flux handbook: A comprehensive database of critical and threshold flux values for membrane practitioners, Amsterdam (Netherlands), Elsevier. http://dx.doi. org/10.1016/B978-0-12-801589-6.00001-2

Tezcan Ü, Uğur S, Koparal AS, Öğütveren ÜB. 2006. Electrocoagulation of olive mill wastewaters. Sep. Purif. Technol. 52, 136-141. http://dx.doi.org/10.1016/j.seppur. 2006.03.029 